\title{
Article
}

\section{Carbon Stock in Sub-national Level Forests in Nepal}

\author{
Bhoj Raj Ghimire 1,2*, Bhogendra Mishara ${ }^{2,3}$ Masahiko Nagai ${ }^{4}$, Kitamoto Asanobu ${ }^{5}$, and Nophea \\ Sasaki ${ }^{6}$ \\ 1 Faculty of Science, Health and Technology, Nepal Open University, Lalitpur, Nepal bghimire@nou.edu.np \\ 2 Science Hub, Lalitpur, Nepal, bmishra@sciencehub.org.np \\ ${ }^{3}$ Policy Research Institute, Kathmandu Nepal \\ 4 Department of Sustainable Environmental Engineering, Yamaguchi University, Yamaguchi, 755-8611, \\ Japan nagaim@yamaguchi-u.ac.jp \\ ${ }^{5}$ Digital Content and Media Sciences Research Division, National Institute of Informatics, 2-1-2 Hitotsubashi, \\ Chiyoda-ku, Tokyo 101-8430 Japan. kitamoto@nii.ac.jp \\ 6 School of Environment, Recourses, and Development, Asian Institute of Technology, Post Box No 4 \\ Pathumthani 12120, Thailand; Nopheas@ait.ac.th \\ * Correspondence: bghimire@nou.edu.np;;Tel.: +977-9841-197-233
}

Abstract: United Nations Framework Conventions on Climate Change (UNFCC) their conference of parties (COPs) has continuously considered and agreed reducing emission level in order to minimize the impact of global climate change. Reducing emission due to deforestation and degradation (REDD), was considered as one of the major activities in this regard during Kyoto protocol in 2009 which laid foundation for the participating countries to be compensated financially for reduced carbon emission. Mexico convention -2012 required the countries to develop and implement a transparent and consistent monitoring, reporting and verification (MRV) process. Later in Paris agreement-2015, the parties agreed to limit the global warming to 2 degree centigrade and with further efforts to 1.5-degree centigrade furthering entailing the parties to prepare and communicate nationally determined contributions (NDCs) every five years. Nepal aimed to decrease the average annual deforestation rate by 0.05 percent from existing 0.44 percent in the terai region and 0.1 percent in the Chure. Nepal decided to develop its forest reference level (FRL) in national level for the historical period 2000-2010 considering Carbon dioxide and carbon pools above and below ground. As per the Forestry Sector Strategy, Nepal aims to increase carbon stock growth by at least $5 \%$ by 2025 as compared to 2015 and decrease mean annual deforestation rate to 0.05 . After major change in administrative division in Nepal, forest management responsibility has shifted down to the Sub-national level. But forest resource studies have not been conducted yet in these levels. Despite a small country, Nepal has at least four clear physiological regions. The amount of carbon stock stored by different forest type are different depending upon species distribution, carbon volume and density for each species, and their distribution along ecological and physiological regions. Sal (shorea Robusta), for example, having one of the highest carbon densities, is a major forest types in Nepal. The purpose of this study was to generate forest map of the country, calculate carbon stock, gain and loss, and their rate in each province due to deforestation/afforestation using remote sensing data. Further Sal forest map was generated and its contribution in carbon stock was calculated using averaged national carbon density as well as using regional density method. According to the study, around 5.1 million hectares of Nepali land was forest in 2015 increasing from 4.2 million hectares in 2005. However, Sal forest has decreased during the same period. Province 1 contributed the maximum $(130 \mathrm{Tg})$ and Province 2 the minimum (40Tg) of Carbon stock in 2015. Using the conventional method of calculation with national average density (108.08 t/ha), a total of 36.7T CO $2 \mathrm{yr}^{-1}$ carbon sink was observed in the Country. Whereas, with the new approach of calculation, a total of $44.7 \mathrm{~T} \mathrm{CO}_{2} \mathrm{e}$ of carbon sink per year was estimated during the same period. This approach holds potential for qualifying as a MRV process of Nepal. The subnational level forest and carbon statistics produced during this study can be important assets for the better forest governance. This can also pave way for policy formation and preparation of action plan for sustainable forest management and intervention strategy and obtaining better 
financial incentives participating in reduction of emission due to deforestation and forest degradation (REDD) plus programs.

Keywords: Remote Sensing; Sal; REDD+; Carbon Stock; Sub-national, MRV

\section{Introduction}

During the first ever legally binding climate agreement COP-3, in the United Nations Framework Convention on Climate Change (UNFCCC), Kyoto agreement, 41 states agreed to reduce their emissions for the period of 2008 to 2012 by 5.2\%(UNFCC, 1998). COP-13 decision 2 of the Bali convention(UNFCC, 2008) formally recognized the reducing emission due to deforestation and degradation(REDD) which was rooted back in the Kyoto(Holloway \& Giandomenico, 2009). Later in 2010 COP-16(UNFCC, 2012) in its decision CP.16/1/Add.1/par.70 encourages the developing countries to contribute to the mitigation of the carbon loss by reducing the emission from deforestation and degradation, conserve the forest carbon stock, manage the forest sustainably and enhance the forest carbon stocks. Further in Par 71, the convention requests the developing nations to have national strategy, a forest reference emission level (RFEL) or combination of subnational forest reference emission levels, robust and transparent national forest monitoring system for monitoring and reporting of the REDD activities, and a system for providing information on how the safeguards are addressed to qualify themselves for the financial support program(UNFCC, 2012). $3 / \mathrm{CP} / 17$ in Durban adapted green climate fund (GCF) as a devise to support the developing nations as the compensation to their negative carbon emission taking the share from the industrialized and developed countries(UNFCC, 2013). In Paris COP21 (UNFCC, 2015), the parties agreed to an ambitious target to limit the global warming to $2{ }^{\circ} \mathrm{C}$ and put further efforts to limit the increase in temperature to $1.5{ }^{\circ} \mathrm{C}$. Article 4 of the same agreement further entails the parties to prepare and communicate their nationally determined contributions (NDCs) every five years(Hanna \& Philipp M, 2016).

Nepal has submitted its first NDC(Ministry of Population and Environment Nepal, 2016) within a year from the Paris agreement aiming to enhance Nepal's forest carbon stock by at least 5 percent by 2025 as compared to 2015 . Further it aims to decrease the average annual deforestation rate by 0.05 percent from existing 0.44 percent in the terai region and 0.18 percent in the Chure. One of the contributions aimed to pilot a sub-national project on REDD + and reduce more than 10 million tons of $\mathrm{CO}_{2}$ equivalent by 2020. Similarly, the second NDC was submitted in 2020(GoN, 2020) claiming strong commitment to fighting climate change despite being one of the countries least responsible for climate change. The second NDC states that by 2030 , around $45 \%$ of the total area of the country will be under forest cover.

Nepal has received Forest Carbon Partnership Facility (FCPF) grant of worth US\$ 3.6 million in 2011(Ministry of Forests and Soil Conservation, 2013). Many countries and donor partners including World Bank, DFID/SDC, Finland, USAID, and Japanese government have committed to support Nepal on its endeavor (Ministry of Forests and Soil \& Conservation, 2010). Later, in 2013, Mid-Term report was prepared and submitted by Nepal government which revealed satisfactory progress in the arrangement of National REDD+ implementation. There had been substantial development towards multiple domains including but not limited to land use assessment, forest law, policy and governance, national forest monitoring system and land use change drivers(Ministry of Forests and Soil Conservation, 2013).

A series of stakeholders' meetings were followed by technical discussions to determine the spatial resolution and time period for the development of Nepal's Forest Reference Level (FRL). It was decided to develop such at national level for the historical period 2000-2010. Due to limited data availability, the FRL would include only $\mathrm{CO}_{2}$ and the carbon pools of above and below ground biomass. The preparation of Nepal's FRL and other Technical Annexes with results are voluntary and 
are submitted for the purpose of being awarded with financial benefits in accordance with decisions 13/CP.19, paragraph 2, and 14/CP.19, paragraphs 7 and 8 ("National Forest Reference Level of Nepal (2000 - 2010)," 2016).

The decisions of UNFCCC (12/CP.17) encourage countries to implement REDD+ in national level but, it allows to implement at sub-national level as an interim measure when necessary. The major advantage of implementing it in National level is avoidance of potential internal displacement of emissions. Furthermore, it ensures that national policies and measures of mitigations are properly formulated and acted upon. However, with recent political change in Nepal, there are now three level of governance namely local, provincial, and central. Schedule 4 of the Constitution of Nepal, adopted on 20 September 2015, has provided the provision for the division of the country into seven Provinces, 77 districts and 753 municipalities adopting three tier architectures of governance in local, provincial, and central level delegating power and authority accordingly (Table 1). With this change, the judiciary of the forest management has come to the provincial and local level government except for the conserved national parks and reserves. Studies show that Nepal has lost its forest in the past(Panta et al., 2009). Hence, the necessity of exploring forest, keeping their inventory, assessment of reference level in subnational level has become prominent. There is now a different equation where the lower level governments come to play a bigger role, regarding achievement of national commitments and targets set by central government in national and international forums., So, it is vital that forest status of the country be analyzed by province since the management regime of the forest in the municipality is too granular unless a clear picture of provincial statistics is established

Table.1: Administrative Division of Nepal

\begin{tabular}{|c|c|c|c|c|}
\hline sn. & Provinces & Capital & Area $\left(\mathbf{k m}^{2}\right)$ & Population \\
\hline 1 & Province No. 1 & Biratnagar & 25905 & 4534943 \\
\hline 2 & Province No. 2 & Janakpur & 9661 & 5404145 \\
\hline 3 & Bagamati Province & Hetauda & 20300 & 5529452 \\
\hline 4 & Gandaki Province & Pokhara & 21504 & 2413907 \\
\hline 5 & Lumbini Province & Butwal & 22288 & 4891025 \\
\hline 6 & Karnali Province & Birendranagar & 27984 & 1168515 \\
\hline 7 & Sudur Paschim Province & Dhangadhi & 19539 & 2552517 \\
\hline
\end{tabular}

. Nepal has proposed to develop its FRL based on historical and national level data availability considering only $\mathrm{CO} 2$ and the carbon pools of above and below ground biomass("National Forest Reference Level of Nepal (2000 - 2010)," 2016).

The Mexico convention (UNFCC, 2012)decided that the countries should keep in place the measurement, reporting and verification (MRV) process in place so that it can be periodically generated with the predefined method and in a transparent manner. The MRV data catalogue of Nepal(Conservation, 2013) has included only the development regions, districts and municipalities as the administrative units as provinces did not exist then. Moreover currently, the estimation of emissions and removals of carbon is based on the averaged biomass value rather than considering the fact that different forest species have different carbon density at different physiological regions. Shorea robusta (Sal), one of the most important forest species having the highest carbon stock(Pandey et al., 2014a) which is distributed over all the provinces in Nepal, for example, has different densities in different physiological regions(Pandey et al., 2014b; Thapa-magar \& Shrestha, 2015; Ulvdal, 2016). This can make difference in the carbon stock calculation of the country. Conventional methods of estimating such variable densities can be less feasible. However, due to availability of high temporal resolution remote sensing data and products with global coverage and advancement of machine learning algorithms, this can be achieved with considerably low cost and time. (Ghimire et al., 2017) 
has successfully mapped forest in general as well as Sal forest using time series remote sensing data in terai region of Nepal.

This study will: 1) generate the forest map of Nepal in general and Sal forest in particular using the remote sensing images further extending the methods used by(Ghimire et al., 2017), ii) generate statistics on overall forest area, forest gain and forest loss between the year 2005-2015 in subnational (provincial) level, and iii) calculate the carbon stock, loss, gain and net sequestration using the conventional average density as well as physiology wise densities to highlight the advantage of the later over former method. The result of the study will be helpful for the equitable distribution of the financial support obtained via REDD program to the provincial government for the sustainable development and conservation of the forests. Further, it can be established as a benchmark for transparent and repeatable method for MRV. Finally, contribution of Sal forest for stock and emission presented as the result of this study will be a good starting point to extend the approach for other tree species as different physiological regions are dominated by different species. The finding will also help develop FRL in subnational level (advised though not mandatory) which is one of the most important components in REDD+ initiatives

\section{Materials and Methods}

\subsection{Study Area}

Nepal is located between $26^{\circ} 20^{\prime} 53^{\prime \prime} \mathrm{N}$ to $30^{\circ} 26^{\prime} 51^{\prime \prime} \mathrm{N}$ latitude and $80^{\circ} 03^{\prime} 30^{\prime \prime} \mathrm{E}$ to $88^{\circ} 12^{\prime} 05^{\prime \prime} \mathrm{E}$ longitude. Based on geology and geomorphology, Nepal has been divided into five physiographic regions (Figure 1) running along its east-west length (Land resources Mapping Project (LRMP), 1986). The southern region, namely Terai is the most fertile plain land in the country occupying merely $13.7 \%$ of the total land area of the country. The elevation of the region starts from 63m ending up to 330 from the mean sea level. Churia/Siwalik region is situated just north to the Terai and it runs throughout the country. The region occupies hardly $13 \%$ of total land of Nepal and administratively, it touches 36 district boundaries of the country. As far as the elevation is concerned, it runs from $93 \mathrm{~m}$ to 1955 meters. Siwalik range is the emerging youngest mountain range in the Himalayas. To the north of Churiya, along the southern border of the Himalayas lies Hills occupying around $29.2 \%$ of Nepali land area. This portion envelope parts of 55 districts in Nepal making itself the largest region elevating from $110 \mathrm{~m}$ in the south along river valleys and reaching as high as $3300 \mathrm{~m}$ above the sea level. Further north lies Mid Mountains region, claiming $20.4 \%$ of the total land area and covering parts of 40 districts in the country. The region is characterized by small mountains and steep slope and rugged landscape with the elevation range of 543 meters and 4,951. Finally, the northernmost part of the country, called High Mountain, shares country border with China, contains within itself the highest Himalayan massifs claiming $23.9 \%$ of the total land area of the country. The region covers parts of 25 districts. Needless to mention, the region embraces within it the highest peak of the world mount Everest. Elevation ranges from 1,960 $\mathrm{m}$ to 8,848 $\mathrm{m}$ above the mean sea level. 


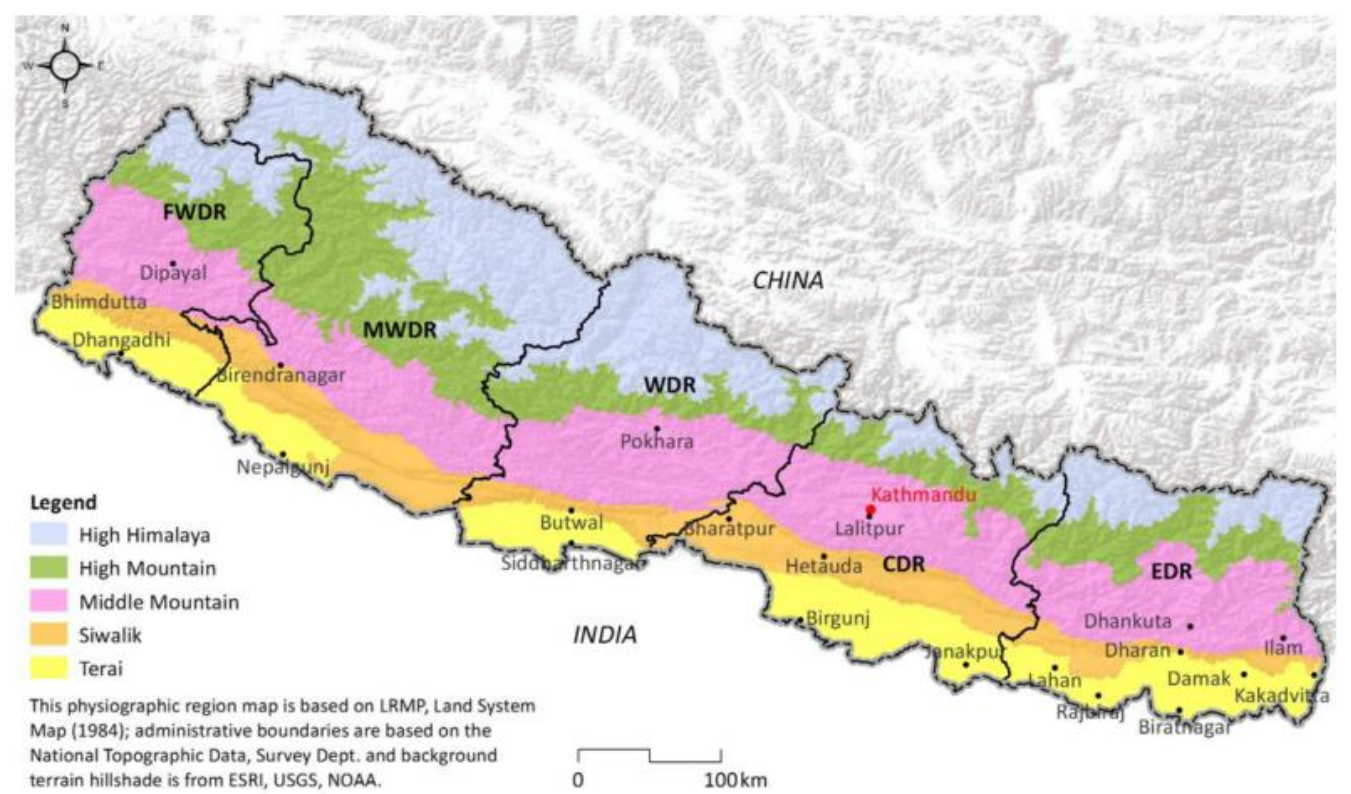

Figure 1. Study area map with altitude information.

\subsection{Forest Mapping}

Supervised machine learning algorithm called support vector machine (SVM) (Vapnik \& Cortes, 1995)was applied to the time series remote sensing-based MODIS data MOD13Q1 (Terra) and MYD13Q1 (Aqua) which in turn were selected on the basis of phonological study(Sun et al., 2012) of the statistics and Boruta algorithm(Kursa \& Rudnicki, 2010) for the classification of the pilot area into mix forest, Sal forest, riverine forest, agriculture and non-forest. This methodology has been adapted from earlier study(Ghimire et al., 2017). Sal forest, mix forest and riverine forest is then merged to form a forest class and rest as a non-forest. The process is extended for the terai region first and then to the entire country using scripting environment with software $R$

\subsection{Carbon Stock and Emission Calculation}

The sources carbon pool considered for the calculation of reference levels in Nepal are above ground and below ground biomass, other are omitted. Deforestation and degradation are regarded as the major reasons for emission of carbon. In this study, only the above ground carbon pool is considered due to its high share in the pool and unavailability of the data below ground.

Total vegetation carbon stocks (CS) in 2005 and 2015 were estimated by summing the carbon stocks by forest categories as follows (Equation 1):

$$
C S=\sum_{p=1}^{5} \sum_{l=1}^{7} \sum_{c=1}^{2} F A_{c l p} \times D C S_{c p}
$$

where $F A_{c l p}$ is the forest area(Ha) of forest type c, province 1 and physiological region $\mathrm{p} D C S_{c p}$ is the default carbon stock ( $\mathrm{MgC}$ ha-1) of forest type $\mathrm{c}$, in that physiological region p. Again, the carbon stocks include only aboveground biomass.

Annual carbon emissions (CE) between 2005 and 2015 are obtained using the stock-change method (method 2) of the IPCC Guidelines (IPCC, 2006):

$$
C E=\frac{\left[C S_{2015}-C S_{2005}\right]}{2015-2005} \times \frac{44}{12}
$$


where, CS2005 and CS2015 are total carbon stocks in 2005 and 2015, respectively, obtained through Eq. (3.5) ( $\mathrm{TgCO} 2$ and $1 \mathrm{TgCO} 2$ is one million $\mathrm{tCO} 2$ ); the ratio $44 / 12$ is the molecular weight ratio of carbon dioxide to carbon. The overall flow is demonstrated in the figure 3.10 below:

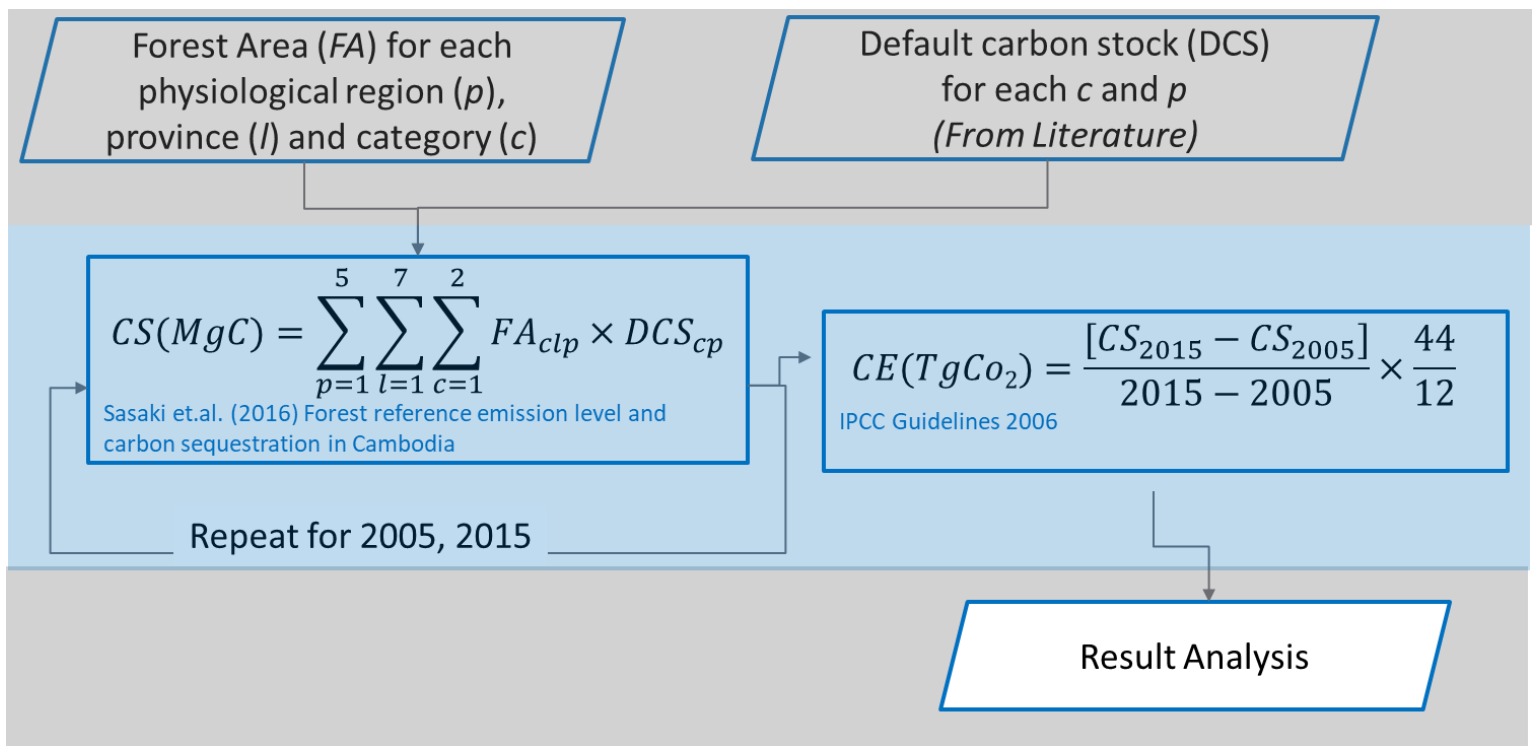

Figure 2: CS and CE Estimation

Some studies in the past show that carbon stocks per hectares of area differ by physiological region(Table 2).

Table 2: Default Carbon Stock

\begin{tabular}{lll}
\multicolumn{3}{c}{ Default Carbon Stock of Forest Categories by } \\
Physiological Region & Overall Forest & Sal (Shorea robusta) \\
\hline Terai & a104.47 & b121.2 \\
Churiya & $\mathrm{a} 97.69$ & $\mathrm{c} 80$ \\
Mid Mountain & $\mathrm{a} 79.42$ & $\mathrm{~d} 120$ \\
High Mountain & $\mathrm{a} 152.36$ & $\mathrm{~d} 120$ \\
High Himal & $\mathrm{x} 152.35$ & $\mathrm{x} 120$ \\
\hline
\end{tabular}

a values are based on the defaults derived in National Forest Resource Assessment (Department of Forest Research and Survey, 2014)

$b$ values are based on the defaults derived from (Pandey et al., 2014b)

c values are based on the defaults derived from (Ulvdal, 2016)

$d$ values are based on the defaults derived from (Thapa-magar \& Shrestha, 2015)

$\mathrm{x}$ values are not found in literature and are the best approximation to the closest physiological region

\section{Results}

\subsection{Sal Forest Map of the Country:}

The Sal forest map of the terai region (Figure 3a), Sal forest, other forest and non-forest map of the year 2015 and 2005 (Figure 3b, 3c) was first generated using the method as discussed in section 2.2. The maps were then clipped with the physiology and provincial boundary of Nepal separately for further analysis. 


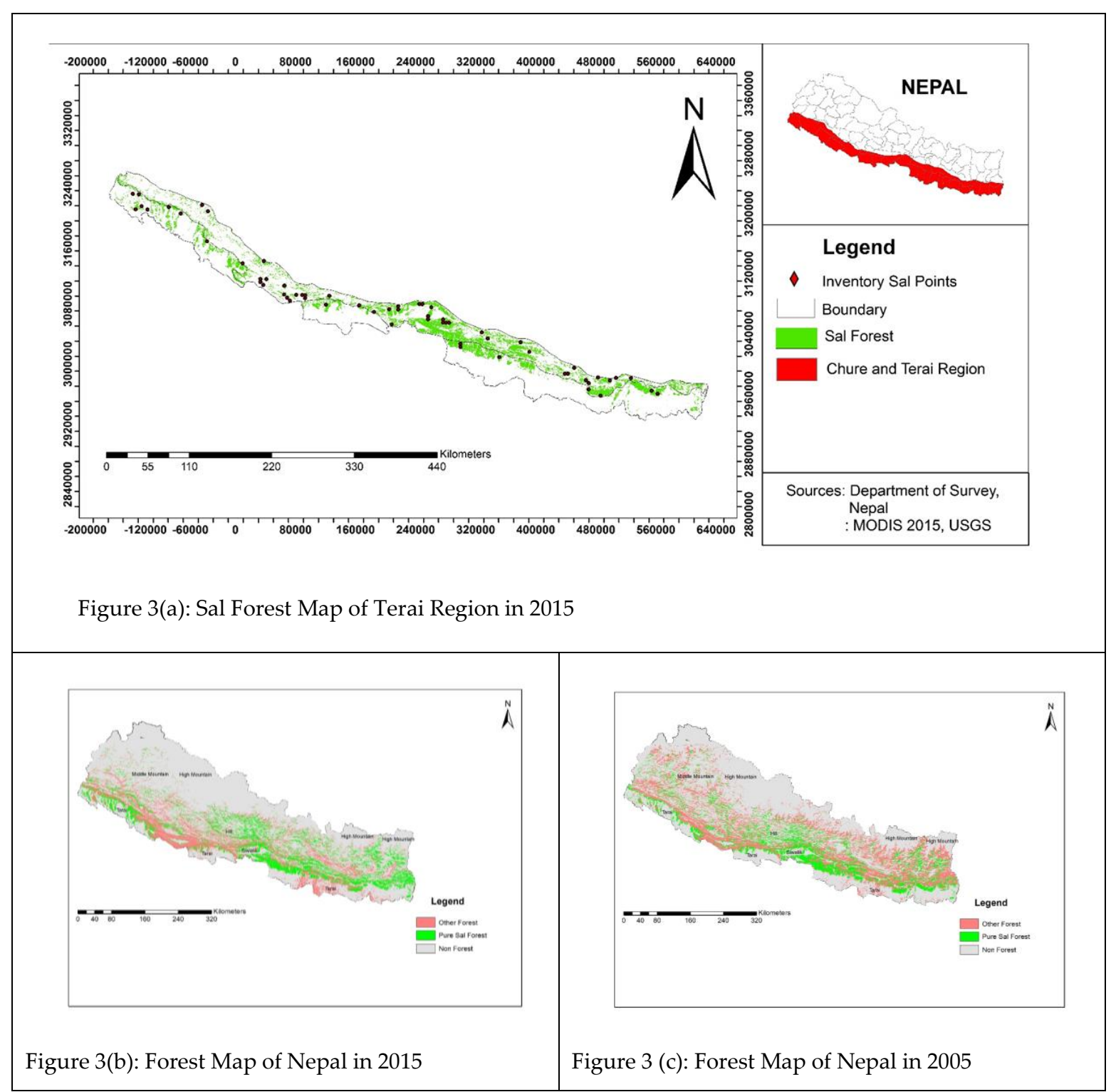

\subsection{Forest Area by Physiological Region}

The analysis of result for the year 2015 shows that Nepal has overall forest area of $5.1 \mathrm{~m}$ ha distributed among all the physiological regions (Figure 4 a). Hills has the maximum forest. Hilly region occupies maximum (41\%) followed by Siwalik (27\%) and mid-mountain (20\%), Terai (9\%) and High mountain (3\%). Around 1.7 million hectares of Nepali forest, which is almost $34 \%$ of overall forest is dominated by Sal. The highest density (59\%) of Sal forest to overall forest is in Terai region followed by Siwalik (40\%) and Hills (33\%). Similarly, the analysis of result for the year 2005 shows that Nepal had overall forest area of $4.2 \mathrm{~m}$ ha distributed among all the physiological regions (Figure $4 \mathrm{~b}$ ). Hills had the maximum forest. Hilly region occupied maximum (40\%) forest followed by Siwalik (31\%), Terai $(15 \%)$, Mid mountain (13\%) and High mountain (1\%). Around 1.8 million hectares of Nepali forest, which is almost $43 \%$ of overall forest was dominated by Sal in 2005. Terai and mid mountain shared highest density of Sal forest to overall forest of $46 \%$ in 2005 , followed by hills (45\%) and Siwalik $(40 \%)$. 


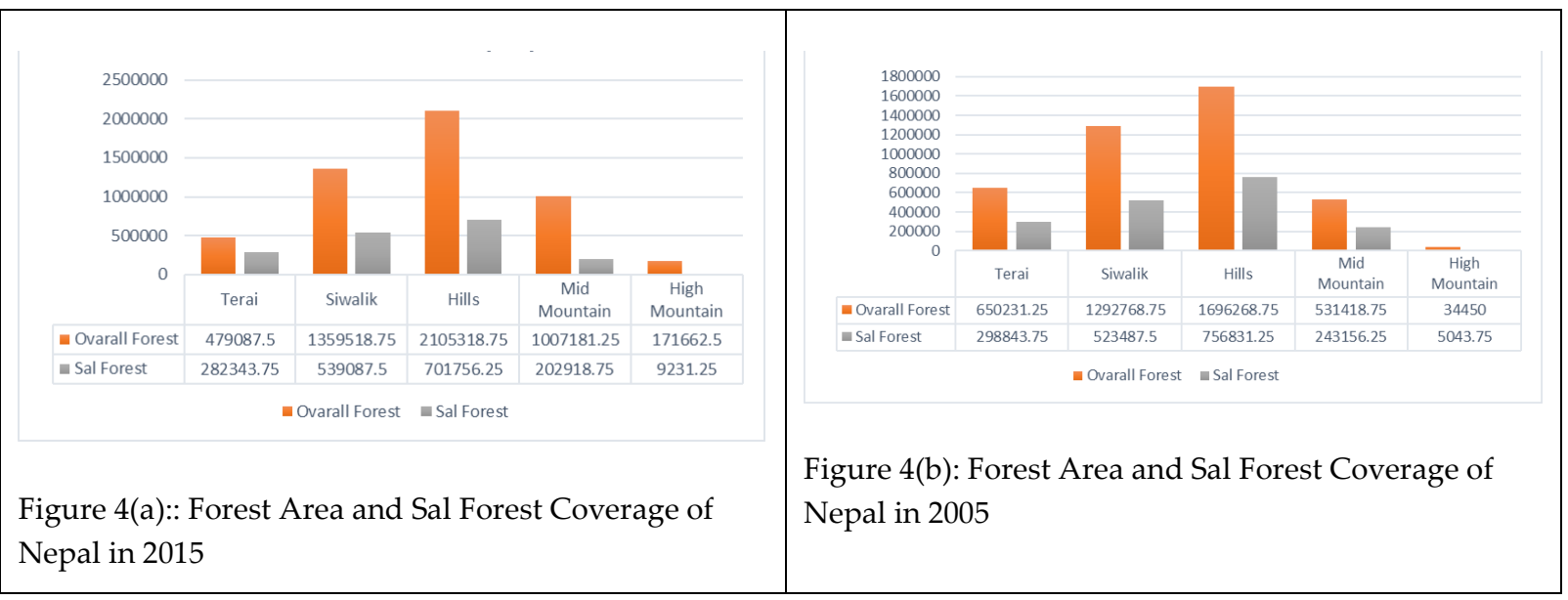

According to the result of our analysis, overall forest area has increased from 4.2 million hectares to 5.1 million hectares in ten years between 2005 and 2015(Figure 5a). However, Sal forest not only failed to increase proportionally but even could not maintain its status back in 2005.

Forest has increased in all the regions except the Terai region (Figure 5b). The overall growth of forest is seen to be $2.2 \%$ per year for last 10 years whereas Terai has been facing an annual loss of $2.6 \%$. Though, overall forest status is seen optimistic, the status of Sal forest is negative. Sal forest has been declining across all the region except a slight growth in the Siwalik range.

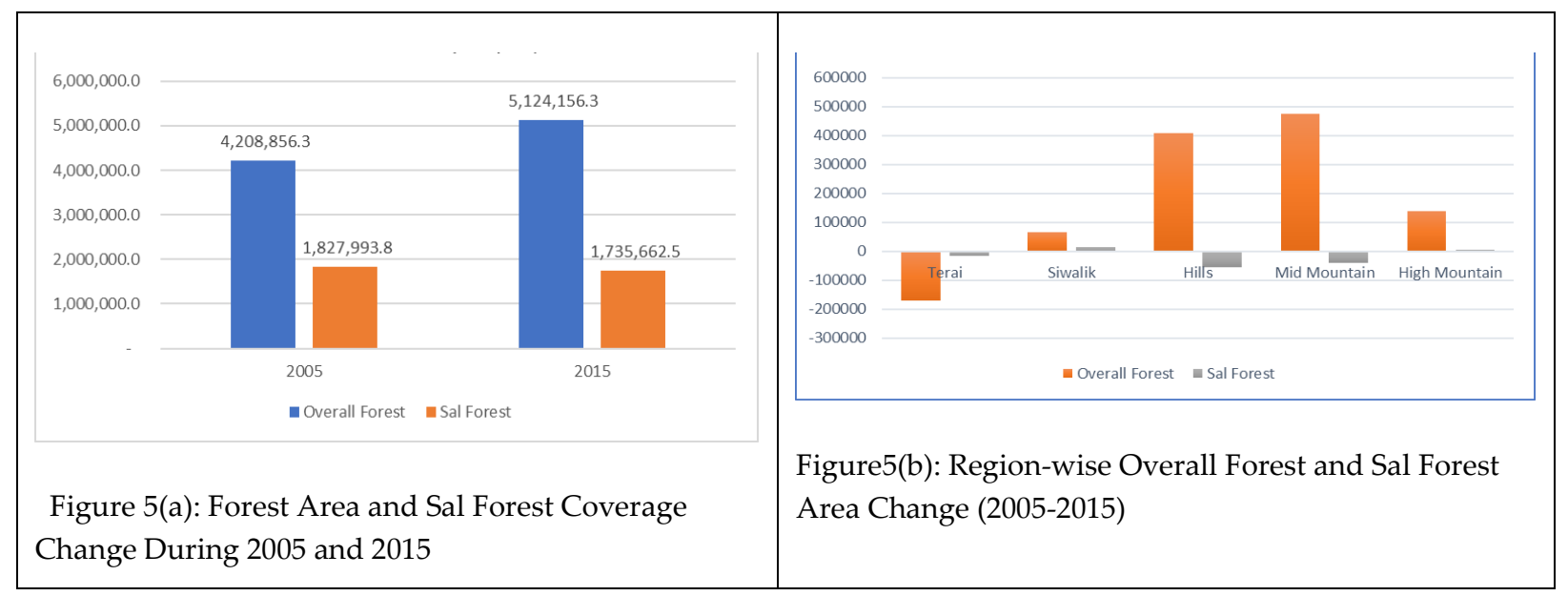

\subsection{Forest Area by Province}

Province one is seen richest of all the remaining provinces in forest resources occupying almost 1.2 million hectares (23\%) of forest (Figure 6.a). Province three and five each occupy around $18 \%$ of forest with almost a million hectares. The highest density (52\%) of Sal forest is available in province two, followed by province four $(43 \%)$, province three $(35 \%)$, province five $(33 \%)$, province one $(31 \%)$ while province seven and province six remain bottom on the list.

As per the result, province five was the richest of all the remaining provinces in forest resources occupying $21 \%$ of forest which was around 900,000 hectares of forest in 2005 (Figure 6.b). Province one followed the list with $19 \%$, three $(18 \%)$, four $(12 \%)$, two $(11 \%)$, whereas seven and eight remained last in the list. The highest density $(60 \%)$ of Sal forest was available in province one, followed by province four (55\%), province three (50\%), province two $(44 \%)$, province seven $(39 \%)$ while province five and six had $26 \%$ of sal dominancy each. 


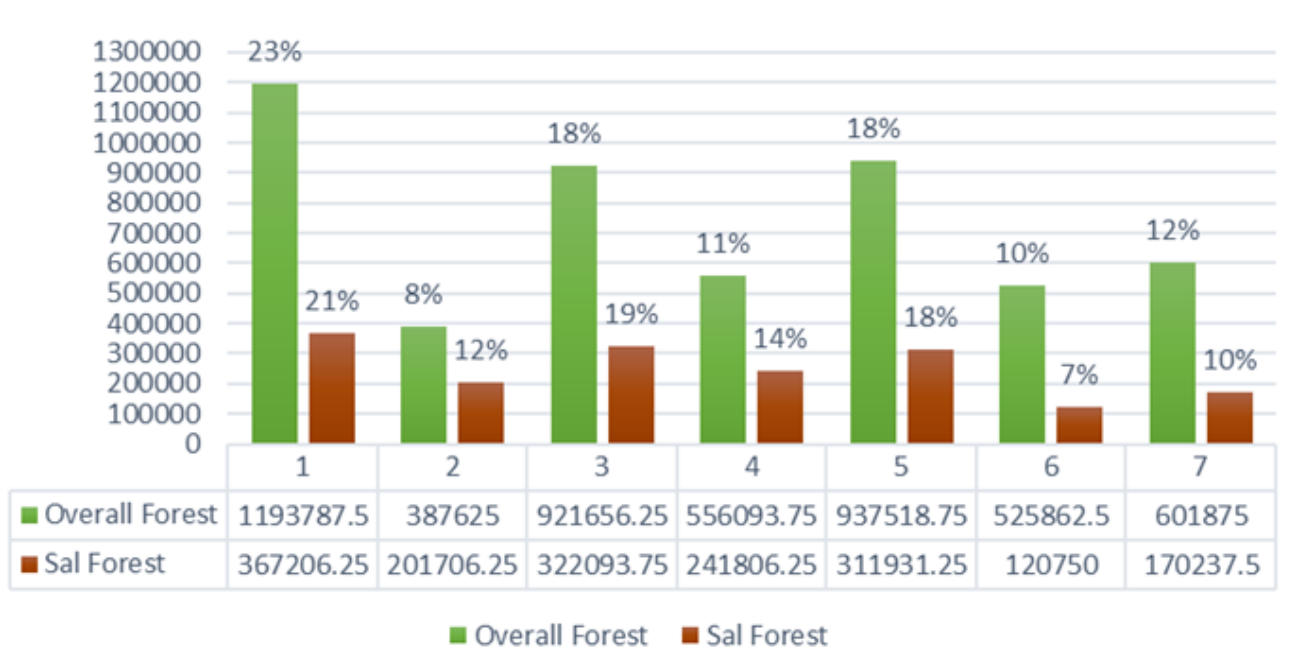

Figure Error! No text of specified style in document.(a): Distribution of Forest Among Sub-national Level 2015

Figure Error! No text of specified style in document.(b): Distribution of Forest Among Sub-national Level 2005

Forest has increased in all the provinces except province two (Figure 7), The overall growth of forest is seen to be $2.2 \%$ per year for last 10 years whereas province two has been facing an annual loss of $1.4 \%$. Though, overall forest status is seen optimistic, the status of Sal forest is negative. Sal forest has been declining across province one, three and four whereas a slight growth is observed in provinces two five and six with net decrease of $0.5 \%$ over last ten years. 


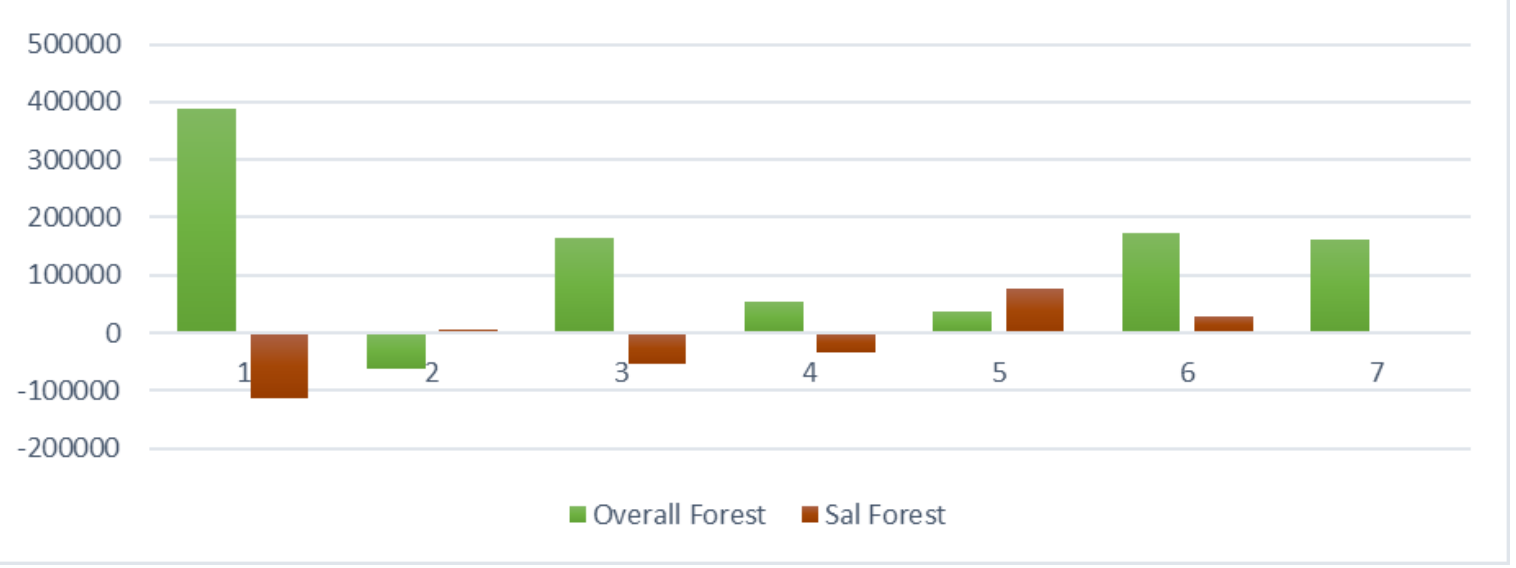

Figure 7: Province-wise Overall Forest and Sal Forest Area Change (2005-2015)

\subsection{Carbon Stock}

In proportion to the area of forest, province one has the highest carbon stock amounting 130 Ton gram $(1 \mathrm{Tg}=106 \mathrm{Kg})$ in 2015 followed by province five and province three (Figure 8a). Province seven, six and four have almost $60 \mathrm{Tg}$ of Carbon. Province two has least carbon stock of around only $40 \mathrm{Tg}$. Total carbon stock contribution of Sal forest in province one is highest with $38 \mathrm{Tg}$ followed by province three. This in contrary to total carbon stock by overall forest where province five has higher contribution.

According to the result of data processing in 2005, province five had the highest carbon stock amounting around 100 Ton gram $(1 \mathrm{Tg}=106 \mathrm{Kg})$, followed by province one $(87 \mathrm{Tg})$ and province three $(82 \mathrm{Tg}$ ). The list is followed by provinces four, two, seven and lastly six(Figure 8b, ). In 2005 too, carbon stock contribution of Sal forest in province one was highest with $49 \mathrm{Tg}$ followed by province three $(39 \mathrm{Tg})$. The list was followed by carbon stock contribution of Sal forest in province four $(28 \mathrm{Tg})$.

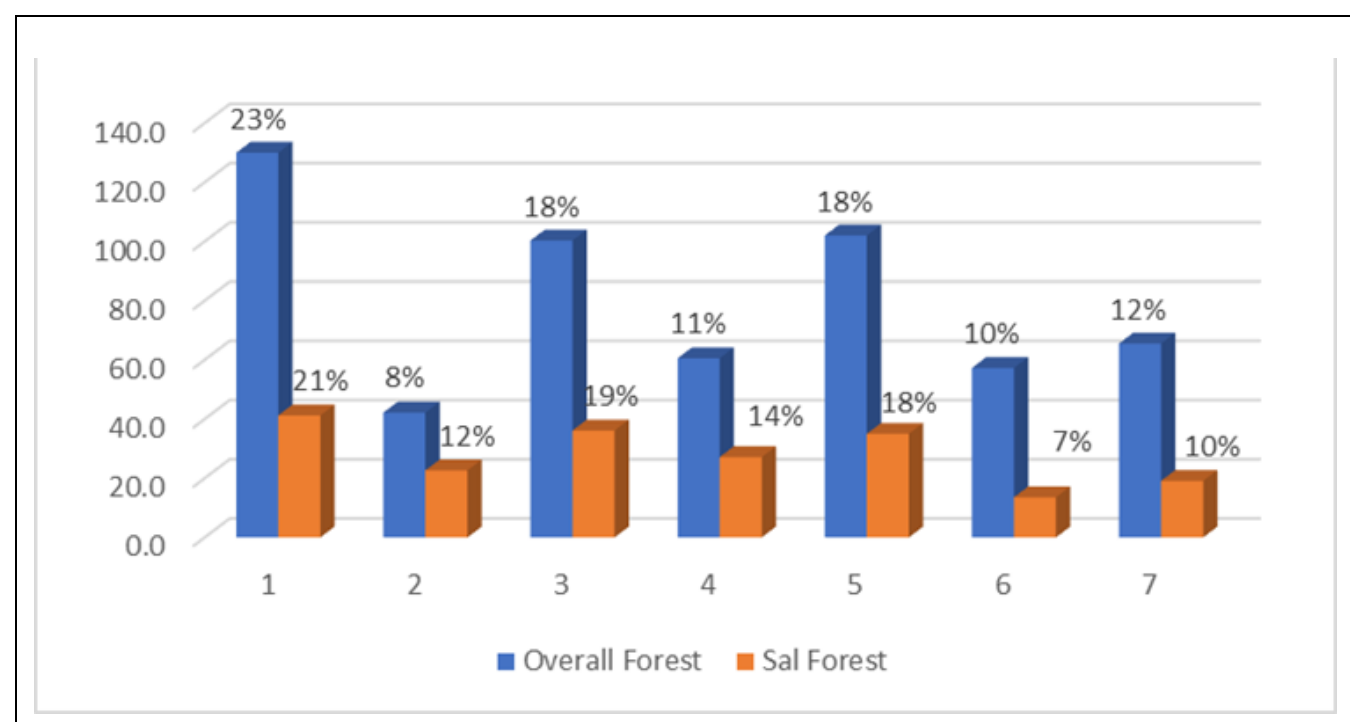

Figure 8(a): Carbon Stock Distribution in Sub-national Level (2015) 


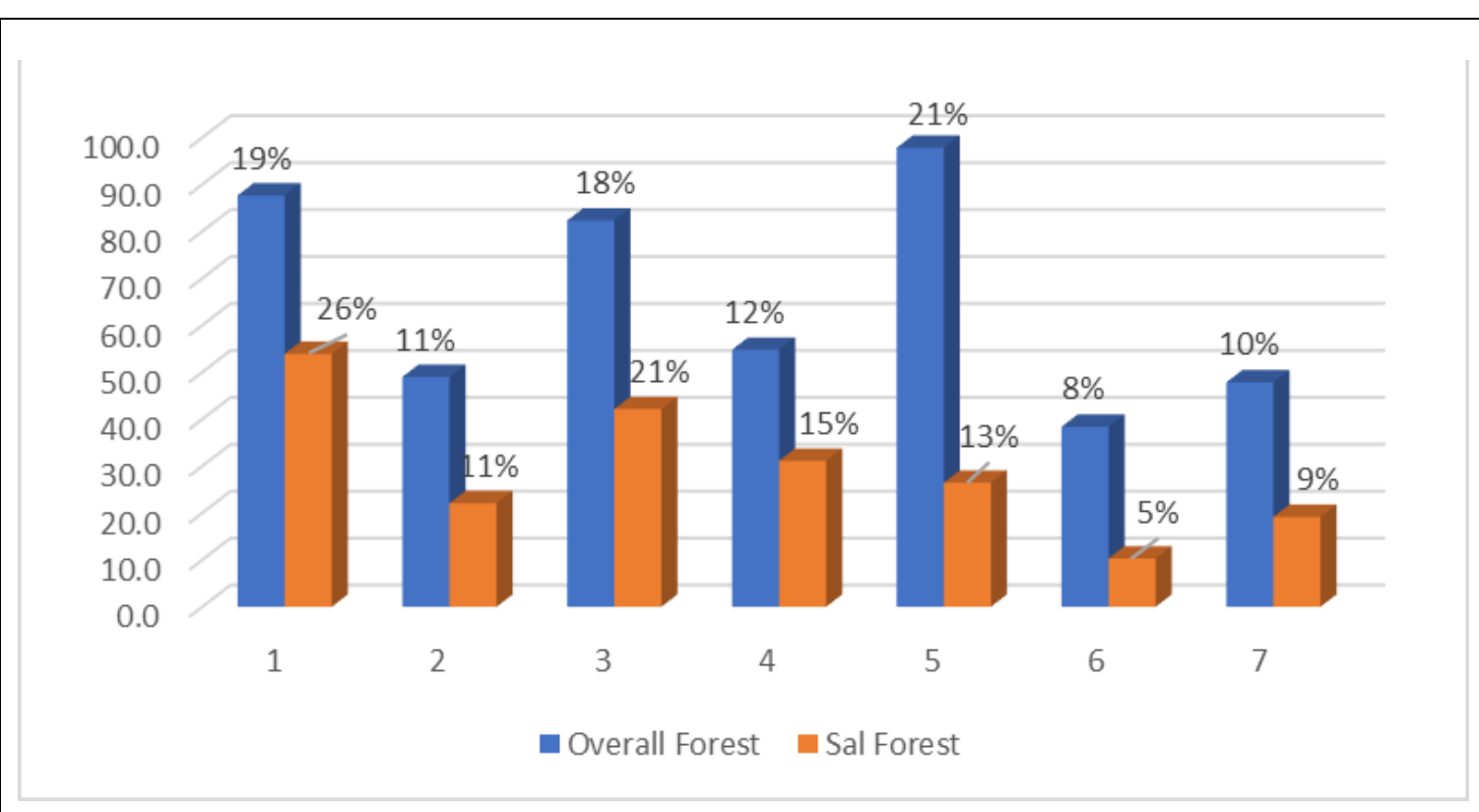

Figure 8(b): Carbon Stock Distribution in Sub-national Level (2005)

\subsection{Carbon Emission/ Sequestration}

As per the result, all the provinces except province two have negative emission with province one topping the list with net sequestration of $18.6 \mathrm{Tg}$ of $\mathrm{CO} 2$ per year (Figure 9). Province three and six and seven are almost similar negative emission (meaning carbon sequestration) whereas province two has been positive emission between 2005 and 2015. Surprisingly, province two has shown 0.21 $\mathrm{Tg}$ of $\mathrm{CO} 2 \mathrm{e}$ per year from Sal forest whereas province one, three, four and seven have been contributing emission of $\mathrm{CO} 2$ due to loss of Sal forest during same period. A total of $44.7 \mathrm{~T} \mathrm{CO} 2 \mathrm{e}$ of carbon sink per year is is estimated during the same period. If national average density $(108.08 \mathrm{t} / \mathrm{ha})$ were used only $36.7 \mathrm{~T} \mathrm{CO} 2$ would be obtained per year.

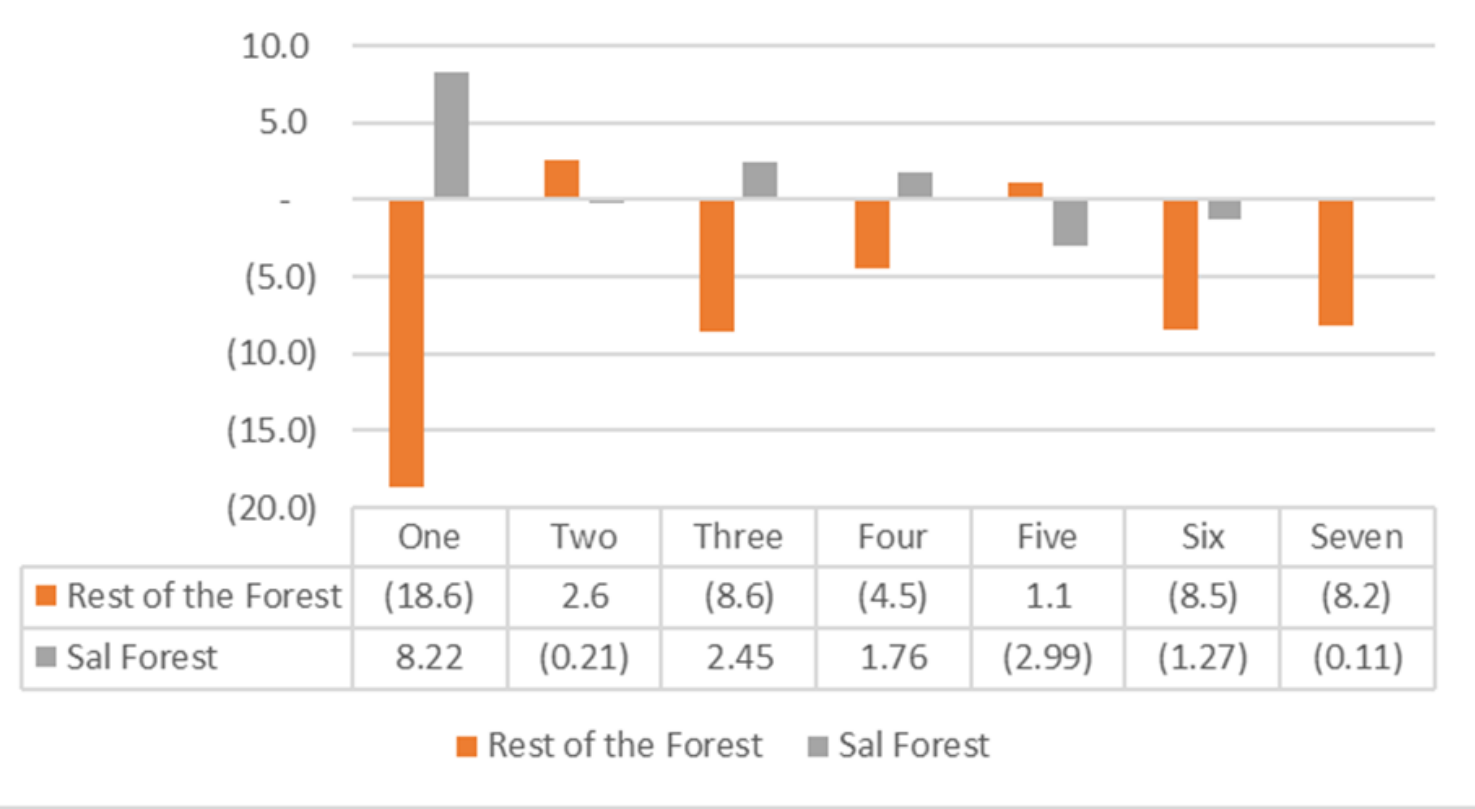

Figure9: Net Carbon Sequestration by Forest of Nepal and Contribution by Sal Forest between 2005 and 2015 


\section{Discussion}

The mapping of forest in general and Sal forest in particular for the year 2015 suggested that 5.1 million hectares of Nepali land was covered by forest out of which $34 \%$ was Sal. According to FRA, 5.9 million hectares of Nepali land was forest. Since, our study does not consider other wooded land(OWL) as forest, both the results are comparable. Same study when repeated for the year 2005 estimated only 4.2 million hectares of land to be forest but almost $43 \%$ of it was Sal. This suggests increment of forest area between 2005 and 2015 but at the same time there has been a decrease in Sal forest area in whole of Nepal. Earlier study(("National Forest Reference Level of Nepal (2000 - 2010)," 2016)) also indicated increase of forest area between 2000 and 2010. This is encouraging result for forest managers however, Sal forest which has high economic value and one of the most important forest types in Nepal has decreased in the same period. During the field visit, major activities responsible for deforestation and degradation in the Terai region was observed to be illegal logging, expansion of high-tension line, construction of infrastructures, irrigation, agricultural activities, and road expansion.

The results implied, progress in forest area change is promising in Siwalik, hills and midmountains where as it falling in the Terai. The community forests in the upper foot hills in Nepal has been very popular, and a very good success story to share, for forest communities in this region. Sal forest on the other hand is decreasing across all the regions with an exception of Siwalik. Coming to administrative boundary (the latest executing administrative unit of the country is province), province one and province six have highest per year increment rate of almost $5 \%$. Of the two, province six is positive even in terms of Sal forest change. Province one is losing Sal forest with highest rate of $2.4 \%$. Province five had the highest carbon sink due to forest followed by province one and three in 2005 but by 2015 the scenario changed and province one ranked top in the list followed by five and three respectively. The rate of carbon sink per year was little different however where province five had slower rate as compared to three, six, seven and four. Province two had positive carbon emission between 2005 and 2015 due to loss of overall forest area, but there had been a slight inclination of carbon sink of $0.2 \mathrm{Tg} \mathrm{CO}_{2}$ e due to increment of Sal forest area. This implies the change in the forest equation over last ten years.

(Sasaki et al., 2016) have used Quick Bird, SPOT-4 and forest inventory data for estimating subnational carbon sequestration and forest reference emission level in Cambodia. So, use of higher resolution remote sensing data could be used to map Sal forest and access the carbon stock for Nepal if adequate time series data are available to cover the whole country and the researcher is equipped with the budget and other resources in order to acquire and process these data sets.

\section{Conclusions}

Overall forest area, Sal forest area and their changes for the last 10 years was estimated not only over five physiological regions but also their distribution over newly formed provincial boundaries. It was found that the new approach of estimating the Stock on the basis of stock density per forest category has advantage over conventional method of calculating with national forest average stock.

The study has shown equitable distribution of forest resources in all the provinces. Now, it is up to the provincial governments to manage, maintain and enhance the current forest cover so that they can be benefitted from forest products and boost their economy. This understanding is important to introduce appropriate management interventions to achieve sustainable and climate resilient forest in the country. The sub-national carbon stock comparison and calculation of change of rate in last ten years (between 2005 and 2015) is the first ever study done in Nepal.

This study has come in a very crucial time in the political scenario of Nepal where the power decentralization process has just started with the formation of first provincial government in the history of Nepal. This can form a baseline study for sustainable use and management of natural 
resources in each province. Organizations working in forestry sector, government, community forests and international regulating bodies can be equally benefited from the output of this study. The maps generated during this study can serve as a good tool for sustainable forest management, change monitoring and monitoring of carbon stock in the forest. The approach is very useful to generate temporal maps of forest species types over shorter period in a very low cost. This study can be scaled down to municipalities level (the lowest and yet very power administrative unit of Nepal) so that each unit can come up with the dominating forest species distribution and their share. Further, they can assess the carbon pools in local context and can formulate policies as well as management interventions in local level. They can determine the local reference forest emission level and establish monitoring plan. The approach can be used as a benchmark for the periodic update of the FRL in the national as well as subnational level of the country. It also has a high potential to act as a transparent MRV process which is an integral part of REDD plus initiative. The carbon stock calculation considering species level density at different physiological regions might prove beneficial for REDD plus initiatives.

Acknowledgment: We would like to acknowledge the data and resource support from The Department of Forest, Nepal government, the staff members and the nature scientists from Chitwan National park. We would like to provide special thanks to Amrit Kadel and Raul A. Ramirez for their contribution in running through English style and grammar.

Author Contributions: Bhoj Raj Ghimire conceived and designed the data and experiments. Bhoj Raj Ghimire, Kitamoto Asanobu, Bhogendra Mishra, Masahiko Nagai, and Nophea developed the methodology and performed experiments. Bhoj Raj Ghimire, and Nophea Sasaki contributed to the analysis and interpretation of the results. Bhoj Raj Ghimire wrote the original draft and all the authors contributed to review and editing of the manuscript.

Conflicts of Interest: The authors declare no conflict of interest.

\section{References}

Conservation, M. of F. and S. (2013). MRV Data Catalog. REDD Forestry and Climate Change Cell, September.

Department of Forest Research and Survey. (2014). Terai Forest of Nepal. FOREST RESOURCE ASSESSMENT NEPAL.

Ghimire, B. R., Nagai, M., Tripathi, N. K., Witayangkurn, A., Mishara, B., \& Sasaki, N. (2017). Mapping of Shorea robusta forest using time series MODIS data. Forests, 8(10), 384. https://doi.org/10.3390/f8100384

GoN. (2020). Second Nationally Determined Contribution (NDC). 0-21.

Hanna, B., \& Philipp M, R. (2016). The Paris Climate Agreement: Is it sufficient to limite climate change? DIW Roundup, 91.

Holloway, V., \& Giandomenico, E. (2009). The History of REDD Policy. Carbon Planet, December, 20. www.carbonplanet.com

IPCC. (2006). IPCC Guidelines for National Greenhouse Gas Inventories, Prepared by the National Greenhouse Gas Inventories Programme, Eggleston H.S., Buendia L., Miwa K., Ngara T. and Tanabe K. (eds). Published: IGES, Japan.

Kursa, M. B., \& Rudnicki, W. R. (2010). Feature Selection with the Boruta Package. Journal Of Statistical Software, 36(11), 1-13. https://doi.org/Vol. 36, Issue 11, Sep 2010

Land resources Mapping Project (LRMP). (1986). Geology report. Land Resources Mapping Project (LRMP).

Ministry of Forests and Soil Conservation. (2013). Mid Term Report. 1-88.

Ministry of Forests and Soil, \& Conservation, G. of N. (2010). Nepal's Readiness Preparation Proposal: REDD 2010-2013. Revision, 1. https://theredddesk.org/sites/default/files/resources/pdf/2012/rpp_nepal_revised_october.pdf

Ministry of Population and Environment Nepal. (2016). NATIONALLY DETERMINED CONTRIBUTIONS. 
http://www4.unfccc.int/ndcregistry/PublishedDocuments/Nepal First/Nepal First NDC.pdf National Forest Reference Level of Nepal (2000 - 2010). (2016). Ministry of Forests and Soil Conservation.

Pandey, S. S., Maraseni, T. N., \& Cockfield, G. (2014a). Carbon stock dynamics in different vegetation dominated community forests under REDD+: A case from Nepal. Forest Ecology and Management, 327, 40-47. https://doi.org/10.1016/j.foreco.2014.04.028

Pandey, S. S., Maraseni, T. N., \& Cockfield, G. (2014b). Carbon stock dynamics in different vegetation dominated community forests under REDD+: A case from Nepal. Forest Ecology and Management, 327, 40-47. https://doi.org/10.1016/J.FORECO.2014.04.028

Panta, M., Kim, K., \& Joshi, C. (2009). Temporal mapping of deforestation and forest degradation in Nepal: Applications to forest conservation. Forest Ecology and Management, 256(9), 1587-1595. https://doi.org/10.1016/j.foreco.2008.07.023

Sasaki, N., Chheng, K., Mizoue, N., Abe, I., \& Lowe, A. J. (2016). Forest reference emission level and carbon sequestration in Cambodia. Global Ecology and Conservation, 7, 82-96. https://doi.org/10.1016/j.gecco.2016.05.004

Sun, H., Xu, A., Lin, H., Zhang, L., \& Mei, Y. (2012). Winter wheat mapping using temporal signatures of MODIS vegetation index data. International Journal of Remote Sensing, 33(16), 5026-5042. https://doi.org/10.1080/01431161.2012.657366

Thapa-magar, K. B., \& Shrestha, B. B. (2015). Carbon Stock in Community Managed Hill Sal ( Shorea robusta ) Forests of Central Nepal. Journal of Sustainable Forestry, 34(5), 483-501. https://doi.org/10.1080/10549811.2015.1031251

Ulvdal, P. (2016). Stand Dynamics and Carbon Stock in a Sal Dominated Forest in Southern Nepal. 264.

UNFCC. (1998). Kyoto Protocol to the united nations framework convention on climate change. UNFCC, 58(2). https://doi.org/10.51663/pnz.58.2.07

UNFCC. (2008). COP-13 Bali. UNFCC, 10(2), 69. https://doi.org/10.1016/S0378-777X(83)80162-0

UNFCC. (2012). COP-16. UNFCC, March, 1-31. https://doi.org/10.4135/9781412971867.n129

UNFCC. (2013). UNFCC Durban. UNFCC, 43(3), 127-129.

UNFCC. (2015). UNFCC Paris Agreement. UNFCC, 45(4), 471-474.

Vapnik, V., \& Cortes, C. (1995). Support- Vector Networks. AT \& T Bell Labs, 20(2), $273-297$. https://doi.org/10.1111/j.1747-0285.2009.00840.x 
Appendix A

Region-wise Forest Area Change Between 2005 and 2015

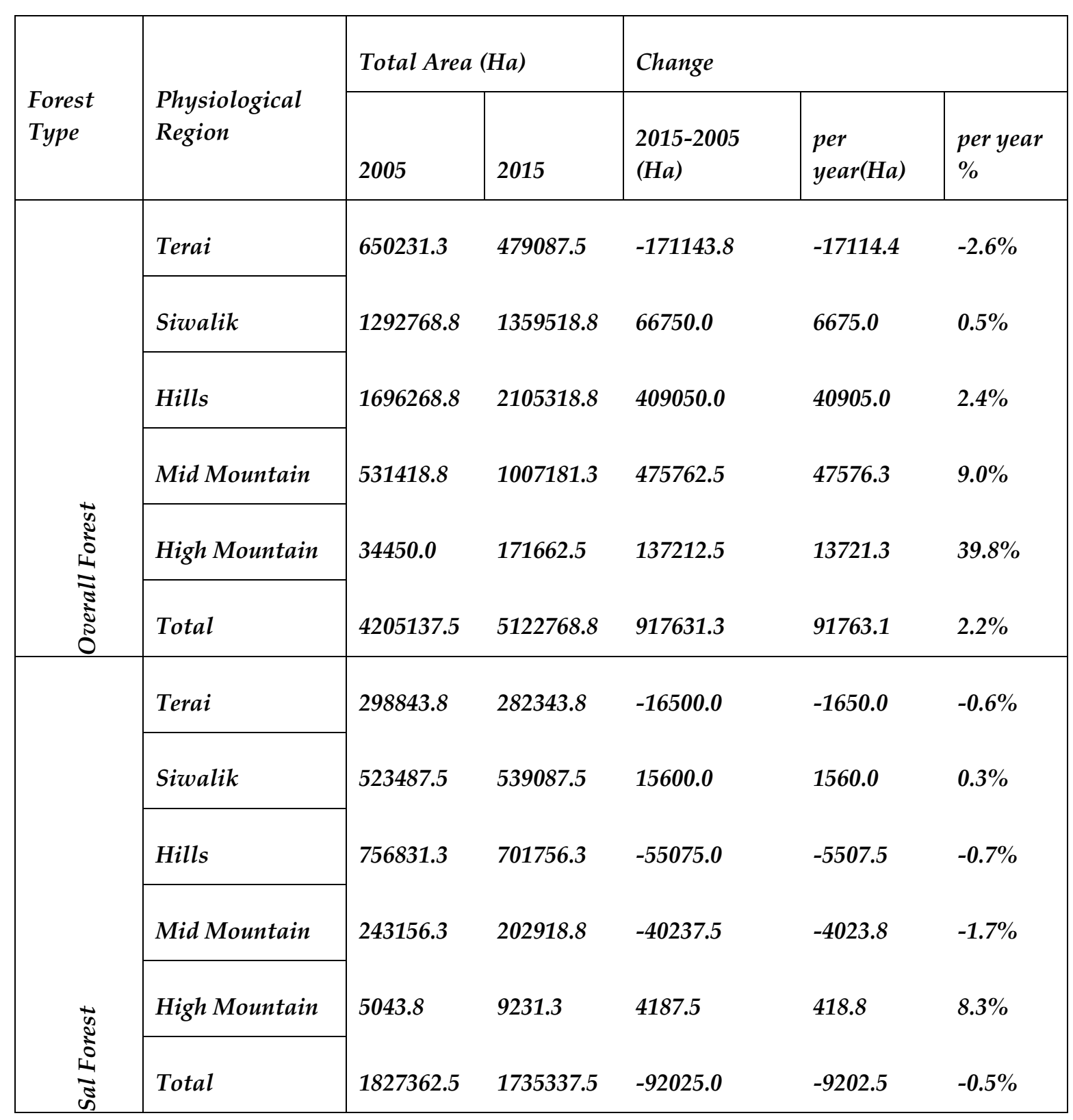




\section{Appendix B}

Table Error! No text of specified style in document..2: Province-wise Forest Change between 2005 and 2015

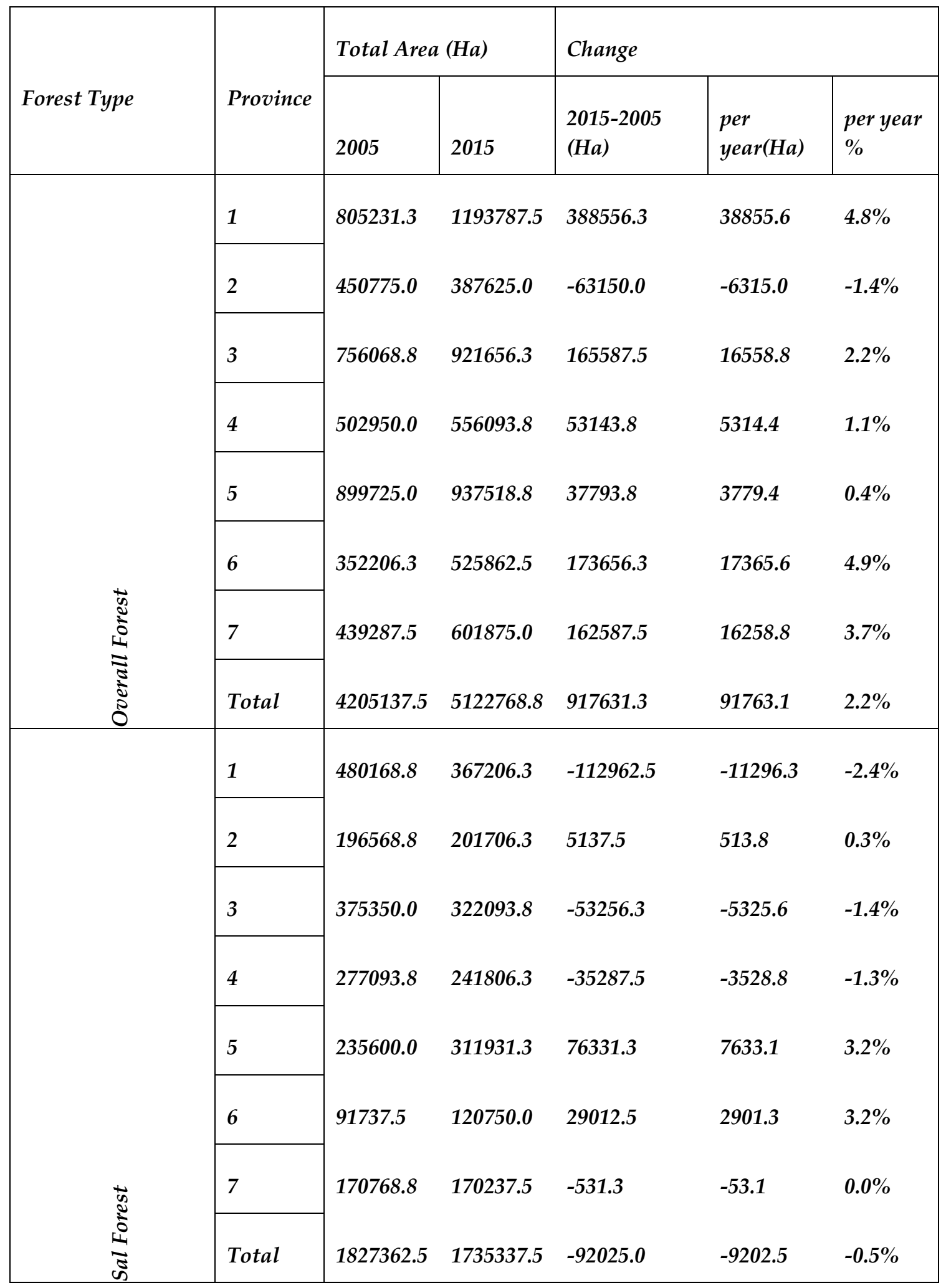


Appendix C

Table Error! No text of specified style in document..3: Carbon Stock by Province per Physiological Region (2015)

\begin{tabular}{|c|c|c|c|c|c|}
\hline \multicolumn{4}{|c|}{ Overall Forest } & \multicolumn{2}{|l|}{ Sal Forest } \\
\hline Province & Region & $\operatorname{Area}(\mathrm{Ha} a)$ & Carbon Stock(tg) & $\operatorname{Area}(\mathrm{Ha})$ & $\begin{array}{l}\text { Carbon } \\
\text { Stock }(t g)\end{array}$ \\
\hline & High Mountain & 13056.3 & 1989250.3 & 6.3 & 750.0 \\
\hline & Mid Mountain & 281412.5 & 42876008.5 & 51606.3 & 6192750.0 \\
\hline & Hill & 647881.3 & 51454728.9 & 187731.3 & 22527750.0 \\
\hline & Siwalik & 107268.8 & 10479084.2 & 33293.8 & 2663500.0 \\
\hline & Terai & 81731.3 & 8538463.7 & 53856.3 & 4308500.0 \\
\hline- & Total & 1193743.8 & 129974819.5 & 367175.0 & 38186200.0 \\
\hline & Siwalik & 190575.0 & 18617271.8 & 104262.5 & 8341000.0 \\
\hline & Terai & 196693.8 & 20548596.1 & 97431.3 & 7794500.0 \\
\hline & Total & 387268.8 & 42165821.5 & 201693.8 & 20976150.0 \\
\hline & High Mountain & 6081.3 & 926539.3 & 18.8 & 2250.0 \\
\hline & Mid Mountain & 133462.5 & 20334346.5 & 11212.5 & 1345500.0 \\
\hline & Hill & 453756.3 & 36037321.4 & 128950.0 & 15474000.0 \\
\hline & Siwalik & 328106.3 & 32052699.6 & 181756.3 & 14540500.0 \\
\hline$m$ & Total & 921406.3 & 100322712.5 & 321937.5 & 33481500.0 \\
\hline & High Mountain & 30687.5 & 4675547.5 & 850.0 & 102000.0 \\
\hline & Mid Mountain & 163068.8 & 24845154.8 & 34237.5 & 4108500.0 \\
\hline & Hill & 297550.0 & 23631421.0 & 162218.8 & 19466250.0 \\
\hline
\end{tabular}




\begin{tabular}{|c|c|c|c|c|c|}
\hline \multicolumn{4}{|c|}{ Overall Forest } & \multicolumn{2}{|l|}{ Sal Forest } \\
\hline Province & Region & $\operatorname{Area}(\mathrm{Ha})$ & Carbon Stock $(\mathrm{tg})$ & $\operatorname{Area}(\mathrm{Ha})$ & $\begin{array}{l}\text { Carbon } \\
\text { Stock }(t g)\end{array}$ \\
\hline & Siwalik & 64768.8 & 6327259.2 & 44500.0 & 3560000.0 \\
\hline & Terai & 118.8 & 12405.8 & 87.5 & 7000.0 \\
\hline & Total & 556106.3 & 60548848.5 & 241806.3 & 25147850.0 \\
\hline & High Mountain & 5137.5 & 782749.5 & 131.3 & 15750.0 \\
\hline & Mid Mountain & 58262.5 & 8876874.5 & 13712.5 & 1645500.0 \\
\hline & Hill & 337856.3 & 26832543.4 & 121556.3 & 14586750.0 \\
\hline & Siwalik & 415181.3 & 40559056.3 & 94218.8 & 7537500.0 \\
\hline & Terai & 120475.0 & 12586023.3 & 82256.3 & 6580500.0 \\
\hline 10 & Total & 936912.5 & 102011033.0 & 311875.0 & 32435000.0 \\
\hline & High Mountain & 66712.5 & 10164316.5 & 4943.8 & 593250.0 \\
\hline & Mid Mountain & 225412.5 & 34343848.5 & 59012.5 & 7081500.0 \\
\hline & Hill & 156518.8 & 12430719.1 & 40268.8 & 4832250.0 \\
\hline & Siwalik & 77237.5 & 7545331.4 & 16531.3 & 1322500.0 \\
\hline & Total & 525881.3 & 57257950.5 & 120756.3 & 12558650.0 \\
\hline & High Mountain & 49981.3 & 7615143.3 & 3281.3 & 393750.0 \\
\hline & Mid Mountain & 145581.3 & 22180759.3 & 33137.5 & 3976500.0 \\
\hline & Hill & 211831.3 & 16823637.9 & 61062.5 & 7327500.0 \\
\hline & Siwalik & 114350.0 & 11170851.5 & 23943.8 & 1915500.0 \\
\hline & Terai & 80106.3 & 8368699.9 & 48793.8 & 3903500.0 \\
\hline & Total & 601850.0 & 65529428.0 & 170218.8 & 17702750.0 \\
\hline
\end{tabular}




\begin{tabular}{|l|l|l|l|l|l|}
\hline \multicolumn{2}{|c|}{ Overall Forest } & & & \\
\hline & & & Carbon Stock(tg) & Area $(\mathrm{Ha})$ & $\begin{array}{l}\text { Carbon } \\
\text { Stock }(\text { tg })\end{array}$ \\
\hline \multirow{2}{*}{ Province } & Region & Area(Ha) & Carest \\
\hline & Grand Total & 5123168.8 & 557810613.5 & 1735462.5 & 180488100.0 \\
\hline
\end{tabular}

Appendix D

Table Error! No text of specified style in document..4: Carbon Stock by Province per Physiological Region (2005)

\begin{tabular}{|c|c|c|c|c|c|}
\hline \multicolumn{4}{|c|}{ Overall Forest } & \multicolumn{2}{|l|}{ Sal Forest } \\
\hline Province & Region & $\operatorname{Area}(\mathrm{Ha})$ & $\begin{array}{l}\text { Carbon } \\
\text { Stock }(t g)\end{array}$ & $\operatorname{Area}(\mathrm{Ha})$ & $\begin{array}{l}\text { Carbon } \\
\text { Stock }(t g)\end{array}$ \\
\hline & High Mountain & 9881.3 & 1505507.3 & 393.8 & 47250.0 \\
\hline & Mid Mountain & 131775.0 & 20077239.0 & 79062.5 & 9487500.0 \\
\hline & Hill & 439856.3 & 34933383.4 & 256181.3 & 30741750.0 \\
\hline & Siwalik & 139906.3 & 13667441.6 & 96881.3 & 7750500.0 \\
\hline & Terai & 83668.8 & 8740874.3 & 47612.5 & 3809000.0 \\
\hline 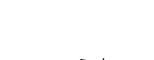 & Total & 805087.5 & 87657927.0 & 480131.3 & 49933650.0 \\
\hline & Siwalik & 176087.5 & 17201987.9 & 103168.8 & 8253500.0 \\
\hline & Terai & 273781.3 & 28601927.2 & 93350.0 & 7468000.0 \\
\hline$\rho$ & Total & 449868.8 & 48981709.5 & 196518.8 & 20437950.0 \\
\hline & High Mountain & 4562.5 & 695142.5 & 287.5 & 34500.0 \\
\hline & Mid Mountain & 91856.3 & 13995218.3 & 37468.8 & 4496250.0 \\
\hline & Hill & 389143.8 & 30905796.6 & 162650.0 & 19518000.0 \\
\hline & Siwalik & 270318.8 & 26407438.7 & 174812.5 & 13985000.0 \\
\hline$m$ & Total & 755881.3 & 82300350.5 & 375218.8 & 39022750.0 \\
\hline
\end{tabular}




\begin{tabular}{|c|c|c|c|c|c|}
\hline \multicolumn{4}{|c|}{ Overall Forest } & \multicolumn{2}{|l|}{ Sal Forest } \\
\hline Province & Region & $\operatorname{Area}(\mathrm{Ha})$ & $\begin{array}{l}\text { Carbon } \\
\text { Stock }(t g)\end{array}$ & $\operatorname{Area}(\mathrm{Ha})$ & $\begin{array}{l}\text { Carbon } \\
\text { Stock }(\text { tg) }\end{array}$ \\
\hline & High Mountain & 11893.8 & 1812131.8 & 1693.8 & 203250.0 \\
\hline & Mid Mountain & 142206.3 & 21666544.3 & 68168.8 & 8180250.0 \\
\hline & Hill & 283443.8 & 22511102.6 & 177443.8 & 21293250.0 \\
\hline & Siwalik & 65331.3 & 6382209.8 & 29787.5 & 2383000.0 \\
\hline & Terai & 81.3 & 8488.2 & 0.0 & 0.0 \\
\hline$\psi$ & Total & 502956.3 & 54761876.5 & 277093.8 & 28817750.0 \\
\hline & High Mountain & 756.3 & 115222.3 & 68.8 & 8250.0 \\
\hline & Mid Mountain & 35968.8 & 5480198.8 & 12081.3 & 1449750.0 \\
\hline & Hill & 277412.5 & 22032100.8 & 73100.0 & 8772000.0 \\
\hline & Siwalik & 415787.5 & 40618280.9 & 69106.3 & 5528500.0 \\
\hline & Terai & 168531.3 & 17606459.7 & 81168.8 & 6493500.0 \\
\hline 10 & Total & 898456.3 & 97823916.5 & 235525.0 & 24494600.0 \\
\hline & High Mountain & 4218.8 & 642768.8 & 1793.8 & 215250.0 \\
\hline & Mid Mountain & 89968.8 & 13707638.8 & 29837.5 & 3580500.0 \\
\hline & Hill & 161893.8 & 12857601.6 & 44318.8 & 5318250.0 \\
\hline & Siwalik & 96143.8 & 9392282.9 & 15787.5 & 1263000.0 \\
\hline 6 & Total & 352225.0 & 38350258.0 & 91737.5 & 9540700.0 \\
\hline & High Mountain & 3131.3 & 477077.3 & 800.0 & 96000.0 \\
\hline & Mid Mountain & 39618.8 & 6036312.8 & 16531.3 & 1983750.0 \\
\hline$\Lambda$ & Hill & 144400.0 & 11468248.0 & 42975.0 & 5157000.0 \\
\hline
\end{tabular}




\begin{tabular}{|c|c|c|c|c|c|}
\hline \multicolumn{4}{|c|}{ Overall Forest } & \multicolumn{2}{|l|}{ Sal Forest } \\
\hline Province & Region & $\operatorname{Area}(\mathrm{Ha})$ & $\begin{array}{l}\text { Carbon } \\
\text { Stock }(t g)\end{array}$ & $\operatorname{Area}(\mathrm{Ha})$ & $\begin{array}{l}\text { Carbon } \\
\text { Stock }(\text { tg) }\end{array}$ \\
\hline & Siwalik & 128956.3 & 12597736.1 & 33881.3 & 2710500.0 \\
\hline & Terai & 123056.3 & 12855686.4 & 76525.0 & 6122000.0 \\
\hline & Total & 439162.5 & 47816013.0 & 170712.5 & 17754100.0 \\
\hline & Grand Total & 4203637.5 & 457692051.0 & 1826937.5 & 190001500.0 \\
\hline
\end{tabular}

Appendix E:

Table Error! No text of specified style in document..5: Net Carbon Sequestration per Year Between 2005 and 2015

\begin{tabular}{|c|c|c|c|c|c|c|}
\hline & \multicolumn{3}{|c|}{ Overall Forest } & \multicolumn{3}{|c|}{ Sal Forest } \\
\hline Province & CS 2015 & CS 2005 & CE per year & CS 2015 & CS2005 & CE per year \\
\hline 1 & 82.9 & 32.0 & (18.6) & 31.4 & 53.8 & 8.22 \\
\hline 2 & 18.8 & 26.0 & 2.6 & 20.1 & 19.6 & $(0.21)$ \\
\hline 3 & 59.6 & 36.3 & $(8.6)$ & 31.4 & 38.0 & 2.45 \\
\hline 4 & 36.9 & 24.7 & $(4.5)$ & 27.2 & 32.1 & 1.76 \\
\hline 5 & 60.1 & 63.0 & 1.1 & 33.8 & 25.6 & (2.99) \\
\hline 6 & 49.9 & 26.7 & $(8.5)$ & 13.8 & 10.4 & $(1.27)$ \\
\hline 7 & 48.3 & 26.1 & $(8.2)$ & 19.5 & 19.2 & $(0.11)$ \\
\hline Total & 356.6 & 234.8 & $(44.7)$ & 177.3 & 198.7 & 7.85 \\
\hline
\end{tabular}


